\title{
Microsatellite variability analysis in farmed catfish (Ictalurus punctatus) from Tamaulipas, Mexico
}

\author{
Laura E. Perales-Flores ${ }^{1}$, Ana María Sifuentes-Rincón ${ }^{1}$ and Francisco J. García de León ${ }^{2}$ \\ ${ }^{1}$ Centro de Biotecnología Genómica, Instituto Politécnico Nacional, Tamaulipas, México. \\ ${ }^{2}$ Programa de Planeación Ambiental y Conservación, Centro de Investigaciones del Noroeste, \\ La Paz Baja, BCS, México.
}

\begin{abstract}
Analysis of cultured catfish from six farms in Tamaulipas, Mexico was achieved using a combination of microsatellite PCR analysis and semiautomatic fluoresce-based detection, in order to provide a first assessment of the genetic variability on cultured catfish in Mexico. Five microsatellites showed extensive polymorphism with allele numbers ranging from 10 and 20 . Overall observed heterozygosity at each locus ranged between 0.76 and 0.91 and the average polymorphic information content (PIC) for the five loci was 0.811 , indicating that these loci can be used for studies of paternity identification, linkage and population genetics. On the basis of the $\mathrm{F}_{\mathrm{ST}}$ values $\left(F_{S T}=0.03829\right.$; $p=0.00000$ ) it appears that there was a small amount of genetic differentiation between the channel catfish stocks. The high intrapopulation allelic diversity was the most remarkable parameter.
\end{abstract}

Key words: Ictaluridae, molecular characterization, genetic variability.

Received: February 3, 2006; Accepted: November 23, 2006.

Genetic markers development have been impacting research in almost every biological area, including aquaculture where they have become an important tool for providing information regarding genetic variability, parentage relationships and the performance of lines in breeding programs (García de León et al., 1998; Spidle et al., 2004; Vandeputte et al., 2004; Rowena et al., 2004; Liu and Cordes, 2004). Currently a wide variety of markers have been developed for different aquaculture species, such markers include allozymes, amplified fragment length polymorphisms (AFLPs), expressed sequence tags (ESTs), microsatellites, mtDNA, random amplified polymorphic DNAs (RAPDs), restriction fragment length polymorphisms (RFLPs) and single nucleotide polymorphisms (SNPs) (Liu and Cordes, 2004). Microsatellites are repetitive elements characterized by mono, di, tri and tetra nucleotide arrays and have become one of the most important tools in genetic studies due to their high degree of polymorphism and conservation between species and families (FitzSimmons et al., 1995; Pépin et al., 1995; Goldstein and Schlotterer, 1999; Liu et al., 1999d; Waldbieser et al., 2001; Cunningham and Meghen, 2001).

Send correspondence to AM Sifuentes. Laboratorio de Biotecnología Animal I, Centro de Biotecnología Genómica, Instituto Politécnico Nacional, Boulevard del Maestro esq. Elías Piña, Col. Narciso Mendoza, Cd. Reynosa, 88710 Tam, México. E-mail: asifuentes@ipn.mx.
The channel catfish (Ictalurus punctatus) is one of the world-wide highlight species in aquaculture and has been subject of several genomic studies which have led to the development of different molecular markers (Carmichael et al, 1992; Waldbieser and Bosworth, 1997; Liu et al., 1998a; 1998b; 1999a; 1999b; 1999c, 1999d); Tan et al., 1999; Waldbieser et al., 2001). Mickett et al. (2003), proposed that understanding the genetic variation within domestic catfish populations is a main requirement for maximizing the selective breeding of this species. Moreover, analysis of catfish genetic resources is also important for establish a baseline date for both genetic enhancement programs and genetic conservation programs.

In the Mexican state of Tamaulipas the most important aquaculture species apart from shrimp is I. punctatus, with the production from this state accounting $53 \%$ of the national catfish crop, some blue catfish (Ictalurus furcatus) are also produced (Tamaulipas-Sedem-Agropesca, 2000). Although several genetic aspects of I. punctatus and I. furcatus are well know from gene mapping, markerassisted selection, gene cloning, engineering and integrated genetic improvement studies (Liu, 2001), in Mexico the genetic variation, breeder fitness and genetic structure of both domestic and native populations of this specie is practically unknown. In fact there is no firm data even on the origin of current cultured I. punctatus, although it is thought they probably originated in the USA (Rosas, 1981). 
Tan et al. (1999) reported a group of microsatellites markers, which were described as effective in analysis of the Ictaluridae genome, especially in studies of genetic resource analysis, stocking success evaluation, population structure, paternity identification and molecular systematics.

The study described in this paper used microsatellite markers to evaluate the genetic variability of culturedcatfish from Tamaulipas Mexico. Since the Mexican catfish industry has been developed with little knowledge on the genetic background of breeder-fish the data produced in this study could help to define more focused management strategies to improve the Mexican catfish industry.

Tissue samples were obtained from six of the most productive catfish farms located in the center of the Mexican state of Tamaulipas, the farms being: Las Delicias (LA), Acuamex (A), Prodatec (P), El Paraìso (EP), El Tomaseño (ET) and La Lajilla (LL). Sample size varied from 23 to 30 fish per farm and DNA was extracted from muscle tissue by a standard method (Sambrook et al., 1989). The total sample number was $n=158$.

Genetic diversity at five microsatellite loci was determinate using primers Ip077, Ip591, Ip265, Ip427 and Ip607 reported as useful for amplification studies in several ictalurid catfish (Tan et al., 1999). The PCR conditions for each loci were individually optimized. Each PCR reaction was used $50 \mathrm{ng}$ of total DNA, 1.25 U of Taq DNA polymerase (Promega Co, Madison, Wi. USA), 0.2 M of unlabeled primer and $0.5 \mathrm{mM}$ dNTP's per 10 L-reaction volume. The concentrations of $\mathrm{MgCl}_{2}$ were $2 \mathrm{mM}$ for Ip265, Ip427 and Ip607 loci and $1.75 \mathrm{mM}$ for Ip077 and Ip591. The PCR products were analyzed in a LI-COR sequencer (LI-COR, Inc. Lincoln, Nebraska USA), 5'-primers being labeled with IRD800 and used at a final concentration of $0.025 \mathrm{M}$ for the Ip265, Ip427 and Ip607 loci and 0.025 M for the Ip077 and Ip591 loci. Amplification temperature profiles were $94{ }^{\circ} \mathrm{C}$ for $30 \mathrm{~s}, 60^{\circ} \mathrm{C}$ for $1 \mathrm{~min}$ and $72^{\circ} \mathrm{C}$ for $2 \mathrm{~min}$, for 30 cycles. The PCR products were denatured at $95{ }^{\circ} \mathrm{C}$ for $5 \mathrm{~min}$ and separated by electrophoresis on $6.5 \%(\mathrm{w} / \mathrm{v})$ denaturing polyacrylamidebisacrylamide gel for $2 \mathrm{~h}$.

Allele size data for each locus were obtained using the SAGA GT software (LI-COR,Lincoln, NE). Numbers of alleles (k), observed (Ho) and expected (He) heterozygosity, allelic frequencies, and the polymorphic information content (PIC, Boststein et al., 1980) for each locus and combinations of loci were estimated using the CERVUS 2.0 software (Marshall et al., 1998). The effective number of alleles was estimated based on the formula: $\mathrm{a}_{\mathrm{e}}=1 / \Sigma x_{i}^{2}$, where $x_{i}$ is the frequency of the $i$ th allele for each locus ( $\mathrm{Li}$ et al., 2004). Heterogeneity in allele frequencies among pair-wise comparisons and exact tests for conformance to Hardy-Weinberg equilibrium (HW) at each locus within samples were performed using the GENEPOP $3.1 \mathrm{~b}$ pro- gram (Markov chain method; Raymond and Rousset, 1995).

The genetic structure of the populations was determined by analysis of molecular variance (AMOVA) using the Arlequin software (Schneider et al., 2000), under a hierarchical design that considered variations among populations and within individuals.

The panel of five microsatellites used in this study exhibited high polymorphism in the total studied population $(n=158)$, with the total number of alleles per locus varying between 10 and 20. The highest number of effective alleles was 8.4 for locus Ip607 and the lowest was 3.1 for locus Ip427 (Table 1). Although the number of detected alleles ranged from 4 for the Ip591 locus in the LD population to 15 for the Ip607 locus in the ET population there were considerable differences in the number of alleles per loci between the farms. Private alleles were also present in the six farms (data not shown).

Average observed heterozygosity by loci for the six cultivated catfish populations ranged between 0.57 for the LL population and 0.77 for the ET population, with an average of 0.63 (Table 1). These values are similar to those described for a research catfish line (I. punctatus) line in Auburn USA using a microsatellite panel which including the five used in our study (Tan et al., 1999) and for selected strains and farmed wild catfish (I. punctatus) populations (Waldbieser et al., 2001). The Prodatec farm (P) showed the highest difference between observed and expected heterozygosity.

Genotype frequencies at all five loci revealed an overall departure from Hardy-Weinberg expectations in three or more loci per farm, this departure being due to a heterozygote deficit strongly influenced by loci Ip 265 and Ip427, which, with the exception of locus Ip427 in the LD population, showed significant HW values in all the populations. The Prodatec farm was the only farm that showed a departure from $\mathrm{H}-\mathrm{W}$ disequilibrium for all loci, suggesting a high rate of inbreeding in this farm (Table 1). Although the small sample-size could be the main explanation for the HW deviation observed in most of the markers and the six farms, other causes have to be considered in to determined the influence of this deviation, these include null alleles (mainly for loci Ip265 and Ip427) and management practices such as the use of a small number of effective breeders which could lead to endogamy.

The loci used in this study are known to be independent (Liu ZJ, Personal Communication). The polymorphism information content (PIC) is an indicator of how many alleles a marker has, and how evenly the frequencies of these alleles are distributed (Boststein et al., 1980) and if a marker has few alleles, or many alleles but with only one being frequent, the PIC will be low. In our study, locus Ip607 had a PIC value of 0.91 and a high effective number of alleles $\mathrm{a}_{\mathrm{e}}=8.4$ while the Ip077 locus had a moderate PIC value of 0.64 with a low effective number of alleles 
Table 1 - Effective number of alleles (ae), expected and observed heterozygosity (He and Ho respectively), polymorphic information content (PIC) and Hardy-Weinberg values (HW) of five microsatellite markers used in six catfish farms in the Mexican state of Tamaulipas, the farms being: Las Delicias (LA), Acuamex (A), Prodatec (P), El Paraìso (EP), El Tomaseño (ET) and La Lajilla (LL).

\begin{tabular}{lccccccc}
\hline $\begin{array}{l}\text { Locus and diver- } \\
\text { sity measure }\end{array}$ & \multicolumn{7}{c}{ Farm } \\
\cline { 2 - 8 } & LD & $\mathrm{A}$ & $\mathrm{P}$ & $\mathrm{EP}$ & $\mathrm{ET}$ & $\mathrm{LL}$ & $\mathrm{OP}$ \\
\hline $\mathrm{Ip} 077$ & 3.7 & 2.5 & 4.7 & 3.9 & 5.4 & 3.1 & 3.8 \\
$\mathrm{a}_{\mathrm{e}}$ & & & & & & & \\
$\mathrm{H}_{\mathrm{o}}$ & 0.76 & 0.56 & 0.68 & 0.80 & 0.8 & 0.3 & 0.77 \\
$\mathrm{H}_{\mathrm{e}}$ & 0.74 & 0.62 & 0.80 & 0.76 & 0.83 & 0.69 & 0.64 \\
$\mathrm{PIC}$ & 0.68 & 0.57 & 0.75 & 0.70 & 0.79 & 0.63 & 0.74 \\
$\mathrm{H}-\mathrm{W}^{*}$ & 0.028 & $\mathrm{~ns}$ & 0.008 & $\mathrm{~ns}$ & $\mathrm{~ns}$ & 0.008 & \\
\hline $\mathrm{Ip} 591$ & & & & & & & \\
$\mathrm{a}_{\mathrm{e}}$ & 2 & 5.7 & 5.5 & 4.1 & 3.7 & 2.6 & 3.9 \\
$\mathrm{H}_{\mathrm{o}}$ & 0.44 & 0.69 & 0.56 & 0.56 & 0.87 & 0.73 & 0.76 \\
$\mathrm{H}_{\mathrm{e}}$ & 0.52 & 0.34 & 0.83 & 0.77 & 0.79 & 0.63 & 0.60 \\
$\mathrm{PIC}$ & 0.47 & 0.80 & 0.79 & 0.72 & 0.68 & 0.58 & 0.74 \\
$\mathrm{H}-\mathrm{W}^{*}$ & 0.031 & $\mathrm{~ns}$ & 0.011 & 0.02 & $\mathrm{~ns}$ & $\mathrm{~ns}$ & \\
\hline
\end{tabular}

\section{Ip 265}

\begin{tabular}{llllllll}
$\mathrm{a}_{\mathrm{e}}$ & 5.2 & 5.6 & 7.1 & 7.4 & 8.3 & 6.0 & 6.6 \\
$\mathrm{H}_{\mathrm{o}}$ & 0.72 & 0.34 & 0.54 & 0.56 & 0.72 & 0.71 & 0.89 \\
$\mathrm{H}_{\mathrm{e}}$ & 0.82 & 0.84 & 0.87 & 0.88 & 0.89 & 0.86 & 0.59 \\
$\mathrm{PIC}$ & 0.78 & 0.80 & 0.84 & 0.85 & 0.86 & 0.81 & 0.88 \\
$\mathrm{H}^{-W^{*}}$ & 0.011 & 0.008 & 0.000 & 0.000 & 0.000 & 0.018 & \\
\hline
\end{tabular}

\section{Ip427}

\begin{tabular}{llllllll}
$\mathrm{a}_{\mathrm{e}}$ & 2.6 & 4.4 & 2.5 & 1.7 & 4.3 & 3.5 & 3.1 \\
$\mathrm{H}_{\mathrm{o}}$ & 0.56 & 0.65 & 0.36 & 0.28 & 0.50 & 0.30 & 0.80 \\
$\mathrm{H}_{\mathrm{e}}$ & 0.62 & 0.79 & 0.62 & 0.44 & 0.78 & 0.72 & 0.43 \\
$\mathrm{PIC}$ & 0.6 & 0.76 & 0.58 & 0.41 & 0.74 & 0.69 & 0.77 \\
$\mathrm{H}-\mathrm{W}^{*}$ & $\mathrm{~ns}$ & 0.009 & 0.000 & 0.015 & 0.000 & 0.000 & \\
\hline
\end{tabular}

\begin{tabular}{llllllll}
\hline Ip607 & & & & & & & \\
$\mathrm{a}_{\mathrm{e}}$ & 9.8 & 7.3 & 8.4 & 6.9 & 9.4 & 8.9 & 8.4 \\
$\mathrm{H}_{\mathrm{o}}$ & 0.92 & 0.82 & 0.76 & 0.76 & 0.967 & 0.80 & 0.91 \\
$\mathrm{H}_{\mathrm{e}}$ & 0.91 & 0.88 & 0.90 & 0.87 & 0.91 & 0.90 & 0.84 \\
$\mathrm{PIC}$ & 0.89 & 0.85 & 0.87 & 0.84 & 0.885 & 0.87 & 0.91 \\
$\mathrm{H}-\mathrm{W}^{*}$ & $\mathrm{~ns}$ & 0.064 & 0.057 & 0.006 & $\mathrm{~ns}$ & 0.000 & \\
\hline
\end{tabular}

\section{Average}

\begin{tabular}{llllllll}
$\mathrm{H}_{\mathrm{o}}$ & 0.68 & 0.61 & 0.58 & 0.59 & 0.77 & 0.57 & 0.63 \\
$\mathrm{H}_{\mathrm{e}}$ & 0.72 & 0.69 & 0.80 & 0.74 & 0.84 & 0.76 & 0.75 \\
\hline
\end{tabular}

*Significant a $\mathrm{p}<0.05$ by the Fisher's exact test. ns = not significant.

$\left(a_{e}=3.8\right)$. The fact that all the loci in our study had PIC values higher than $70 \%$ (Table 1 ) could be considered as good for the selection of polymorphic markers in the study of parental relationships, paternity, and genetic mapping (Blouin et al. 1996; Borrell et al. 2002; Chistiacov et al., 2005) but further studies should be conducted to establish the real dis- crimination power of these markers and to assess their use in identification and pedigree analysis during selection and management of farmed I. punctatus in Tamaulipas.

Based on the analysis of molecular variance summarized in Table 2, global comparisons show that there was little genetic differentiation among farms $\left(F_{S T}=0.03829\right.$; $\mathrm{p}=0.00000)$. Genetic variation in the studied populations was mainly attributable to individual-level variation, with a percentage of variance of $79.6 \%$. Variation between fish within populations represented $16.56 \%$ of the variation while between populations variation was $3.83 \%$. The catfish origins and also the cultivation practices could have been responsible for the low level of genetic differentiation observed between the farms in the $\mathrm{F}_{\mathrm{ST}}$ analysis. According to the catfish producers, the first and unique introduction of a commercial catfish strain into Tamaulipas occurred 25 years ago. There are no reports suggesting recent catfish introductions into the Tamaulipas area so it is probable that the stocks studied have the same origin. In addition a common practice among farmers is to share stock between neighboring-farms (i.e. between P, A and EP), the individual catfish being selected on the basis of their observed phenotypic performance and not their location (i.e. other locations even within the same state).

Even though we do not know the exact number of breeder-fish in different farms in Tamaulipas the high within individual genetic variance $(79.61 \%)$ and between individual within populations $(16.56 \%)$ and the high heterozygosity deficit in all the farms could suggest the existence of high temporal variance in allele frequencies due to variation in reproductive success caused by a small number of effective breeders (Hedgecock et al., 1992). There are numerous studies that clearly demonstrate a loss of genetic diversity following hatchery culture in aquatic organisms (Beaumont, 1994) and an important conclusion drawn in several studies (Sbordoni et al., 1986; Gile and Ferguson, $1990)$ is that the effective population size $(\mathrm{Ne})$ involved in hatchery "mass spawnings" can be much smaller than the apparent number of progenitors used. Moreover, effective population size is strongly affected by the sex ratio of the progenitors (Allendorf and Ryman 1987) and according to the catfish producers this is indeed the case for the Tamaulipas farms.

Micket et al., (2003) carried out a genetic diversity study using AFLP markers and found that there are differences between I. punctatus farms in Alabama USA, these authors emphasizing the importance of this information for the management, conservation and selection of catfish brood-stocks. In Tamaulipas, apparently, the management practices for cultivated catfish are a principal cause of heterozygosity deficit because rather than carrying out a single spawning involving many ripe adults from neighboring farms multiple small spawning with the subsequent pooling of larvae should be attempted. Unfortunately we were unable to obtain any records about the real manage- 
Table 2 - Hierarchical analysis of molecular variance (AMOVA) within and among catfish populations.

\begin{tabular}{lcccc}
\hline Source of variation & Variance component & Percentage of variation & Fixation indices & Probability (p) \\
\hline Among populations & 0.07002 & 3.83 & $F_{\mathrm{ST}}=0.03829$ & $0.000 \pm 0.000$ \\
$\begin{array}{l}\text { Among individuals } \\
\text { within populations }\end{array}$ & 0.30278 & 16.56 & $F_{\mathrm{IS}}=0.17218$ & $0.000 \pm 0.000$ \\
Within individuals & 1.45570 & 79.61 & $F_{\mathrm{IT}}=0.20388$ & $0.000 \pm 0.000$ \\
\hline
\end{tabular}

ment practices in the farms studied and therefore we cannot determine with certainty the causes of the low genetic diversity observed in farmed fish. However, channel catfish producers are now very interested in the design of genetic improvement regimes and our study represents the first step in defining the genetic variation in the actual commercial catfish stocks of this region.

From a conservation point of view, the native catfishes of Northeastern México (Tamaulipas included) are generally poorly known and although several Ictalurus species (furcatus, lupus and punctatus) are recognized various species have not yet been described (Miller, 2005). There has not been an initial baseline evaluation of the native populations of I. furcatus and I. punctatus or any other catfish wild populations in order to start the aquaculture practices in the region, but it has been presumed that domestic and native populations have hybridized (García de León et al., 2005). The consequence of this hybridization is that coadapted gene complexes may have broken down and unique alleles could have been lost in wild fish populations following extensive hybridization and introgression of genes from cultivated fish (Beaumont, 1994). The genetic impact of such hybridization and introgression of genes on native populations requires further attention and the genetic markers tested in our study will find immediate application not only in tracking pedigrees and establishing breeding programs but also in the analyses of local wild-type catfish populations.

\section{Acknowledgments}

The authors are grateful to Acuamex personal for technical assistance and support in obtaining the samples. Financial support was provided by Direccion General de Pesca in Tamulipas and CGPI-IPN 20011090 Research Grants. FJGdL thanks the Instituto Tecnológico de Ciudad Victoria for their support.

\section{References}

Allendorf FW and Tyman N (1987) Genetic management of hatchery stock. In: Ryman N and Utter F (eds) Populations Genetics and Fisheries Management. 1st edition. University of Washington Press, Seattle, pp 141-59.

Beaumont AR (1994) Genetics and aquaculture. In: Beaumont AR (ed) Genetics and Evolution of Aquatic Organisms. 1st edition. Chapman \& Hall, London, pp 447-486.
Blouin MS, Parsons MS, Lacaille V and Lotz S (1996) Use of microsatellite loci to classify individuals by relatedness. Molecular Ecology 5:393-401.

Borrell Y, Álverez J, Vázquez E, Sánchez Prado JA, FernándezPato C, Martínez-Tapia C and Blanco C (2002) Aplicación de marcadores microsatélites a los programas de cultivo del rodaballo Scophthalmus maximus (L., 1758). Bol Inst Esp Oceanog 18:203-209.

Boststein D, White RL, Skolnick M and David R (1980) Construction of genetic linkage map in man using restriction fragment length polymorphism. Am J Hum Genet 32:314331.

Carmichael GJ, Schmidt ME and Morizot DC (1992) Electrophoretic identification of genetic markers in Channel Catfish and Blue Catfish by use of low-risk tissues. Transactions of the American Fisheries Society 121:1:26-35.

Chistiakov DA, Hellemans B, Haley ChS, Law AS, Tsigenopoulos, Kotulas G, Bertotto D, Libertini A and Volckaert FAM (2005) A microsatellite linkage map of the European Sea Bass Dicentrarchus labrax L. Genetics 170:1821-1826.

Cunningham EP and Meghen CM (2001) Biological identification systems: Genetic markers. Rev Sci Tech Off Int Epiz 20:2:491-499.

FitzSimmons NN, Moritz C and Moore SS (1995) Conservation and dynamics of microsatellite loci over 300 million years of marine turtle evolution. Molecular Biology and Evolution 12:432-440.

Hedgecock D, Chow V and Waples RS (1992) Effective population numbers of shellfish brood-stock estimated from temporal variance in allele frequencies. Aquaculture 108:215-32.

Gile SR and Ferguson MM (1990) Crossing methodology and genetic diversity in a hatchery strain of rainbow trout (Onchorynchus mykiss). Can J Fush Aquat Sci 47:719-24.

Goldstein DB and Schlotterer C (1999) Microsatellites. Evolution and Applications. Oxford University Press, New York, 352 pp.

García de León FJ, Canonne M, Quillet E, Bonhomme F and Chatain B (1998) The application of microsatellite markers to breeding programes in the sea bass, Dicentrarchus labrax. Aquaculture 159:303:316.

García de León FJ, Gutiérrez-Tirado D, Hendrickson DA and Espinosa-Pérez H (2005) Fishes of the continental waters of Tamaulipas: Diversity and conservation status. In: Cartron JLE, Ceballos G and Felger RF (eds) Biodiversity, Ecosystems and Conservation in Northern Mexico. Oxford University Press, New York, pp 138-166.

Li SJ, Yang SH, Zhao SH, Fan B, Yu M, Wang HS, Li MH, Liu B, Xiong TA and Li, K (2004) Genetic diversity analyses of 10 indigenous Chinese pig populations based on 20 microsatellites J Anim Sci 82:368:374. 
Liu ZJ and Cordes JF (2004) DNA marker technologies and their applications in aquaculture genetics Aquaculture 238:1-37.

Liu ZJ, Li P, Argue BJ and Dunham, RA (1998a) Inheritance of RAPD markers in channel catfish (Ictalurus punctatus), blue catfish (I. furcatus) and their F1, F2 and backcross hybrids. Anim Genet 29:1-5.

Liu ZJ, Nichols A, Liand P and Dunham RA (1998b) Inheritance and usefulness of AFLP markers in channel catfish (Ictalurus punctatus), blue catfish (I. furcatus) and their F1, F2 and backcross hybrids. Mol Gen Genet 258:260-268.

Liu ZJ, Karsi A and Dunham RA (1999a) Development of polymorphic EST markers suitable for genetic linkage mapping of catfish. Mar Biotechnol 5:437-447.

Liu ZJ, Li P, Argue BJ and Dunham RA (1999b) Random amplified polymorphic DNA markers: Usefulness for gene mapping and analysis of genetic variation of catfish. Aquaculture 174:56-65.

Liu ZJ, Li P, Kucuktas H, Nichols A, Tan G, Zheng X, Argue BJ, Yant R and Dunham RA (1999c) Development of AFLP markers for genetic linkage mapping analysis using channel catfish and blue catfish interspecific hybrids. Trans Am Fish Soc 128:2:317-327.

Liu ZJ, Tan G, Kucuktas H, Li P, Karsi A, Yant DR and Dunham RA (1999d) High levels of conservation at microsatellite loci among Ictalurid Catfishes. J of Here 902:307-312.

Marshall TC, Slate J, Krukk LEB and Pemberton JM (1998) Statistical confidence for likelihood-based paternity inference in natural populations. Mol Ecol 7:639-655.

Mickett K, Morton C, Feng J, Li P, Simmons M, Cao D, Dunham RA and Liu Z (2003) Assesing genetic diversity of domestic populations of channel catfish (Ictalurus punctatus) in Alabama using AFLP markers. Aquaculture 228:91-105.

Miller RR (2005). Freshwater Fishes of México. The University of Chicago Press, Chicago, $490 \mathrm{pp}$.

Pépin L, Amigues Y, Lépingle A, Berthier JL, Bensaid A and Vaiman D (1995) Sequence conservation of microsatellite between cattle (Bos taurus) goat (Carpa hircus) and related species. Exemples of use in parentage testing and phylogeny analysis. Heredity 74:56-61.

Rosas M (1981) Biología Acuática y Piscicultura en México. Serie de Materiales Didácticos de Ciencias y Tecnología del Mar, Secretaría de Educación Pública, México, 254-257 pp.
Rowena M, Romana-Equia R, Ikeda M, Basiao ZU and Taniguchi N (2004) Genetic diversity in farmed Asian Nile and red hybrid tilapia stock evaluated from microsatellite and mitochondrial DNA analysis. Aquaculture 236:31-150.

Sambrook J, Fritsch EF and Maniatis T (1989) Molecular Cloning. A Laboratory Manual. $2^{\text {nd }}$ edition. Cold Spring Harbor Laboratory Press, USA 3:18.8 pp.

Sbordoni V, De Matthaeis E, Cobolli-Sbordoni M, La Rosa G and Matoccia M (1986) Bottleneck effects and the depression of genetic variability in hatchery stock of Penaeus japonicus (Crustacea, Decapada). Aquaculture 57:239-51.

Spidle AP, King TL and Letcher BH (2004) Comparison of genetic diversity in the recently founded Connecticut River Atlantic Salmon population to that of its primary donor stock Maine's Penobscot River. Aquaculture 236:253-265.

Raymond M and Rousset F (1995) GENEPOP versión 1.2: Populations Sofware of Exact Test and Ecumenicism. J Heredity $86: 248-249$

Tan G, Karsi A, Li P, Zheng X, Kucuktas H, Argue BJ, Dunham RA and Liu ZJ (1999) Polymorphic microsatellite markers in Ictalurus punctatus and related catfish species. Mol Ecol 8:1753-1768.

Vandeputte M, Kocour M, Mauger S, Dupont-Nivet M, De Guerry D, Rodina M, Gela D, Vallod D, Chevassus B and Linhart O (2004) Heritability estimates for growth-related traits using microsatellite parentage assignment in juvenile common carp (Cyprinus carpio L.). Aquaculture 235:223-236.

Waldbieser GC and Bosworth BG (1997) Cloning and characterization of microsatellite loci in channel catfish, Ictalurus punctatus Anim Genet 28:295-298.

Waldbieser GC, Bosworth BG, Nonneman DJ and Wolters WR (2001) A microsatellite-based genetic linkage map for channel catfish Ictalurus punctatus. Genetics 158:727-734.

\section{Internet Resource}

Arlequin software version 2000, http://anthro.unige.ch/arlequin. Subsecretaría de Pesca Dirección General de Acuacultura. Norma Oficial Mexicana NOM-010-PESC-1993, http://www. semarnap.gob.mx/gestion/legislación/federal/norma010. htm (October 1, 2005).

Associate Editor: Luiz Lehmann Coutinho 